\title{
Special and Inclusive Education Journal
}

special@unipasby.ac.id

Model Pembelajaran Sentra dan Lingkungan Pada Anak Normal dan Anak Autis

\author{
Aisyah \\ aisyah@,unipasby.ac.id
}

Pendidikan Anak Usia Dini - Universitas PGRI Adi Buana Surabaya

Jl. Dukuh Menanggal XII, Surabaya, 60234, Jawa Timur, Indones

\section{Artikel Info}

Koresponden penulis :

Aisyah

aisyah@unipasby.ac.id

- Diterima 22 Maret 2021

- Direview 22 April 2021

- Disetujui 27 April 2021

- Dipublikasi 30 April 2021

Kata Kunci:

Autis, pembelajaran sentra dan lingkaran

Keywords:

Autism, learning center and circle

dan lingkaran

\begin{abstract}
Abstrak
Tujuan penelitian ini untuk mendeskripsikan model pembelajaran sentra dan lingkungan pada anak normal dan anak autis. Penelitian ini menggunakan pendekatan kualitatif. Metode pengumpulan data menggunakan observasi dan wawancara. Hasil penelitian ini didapatkan Model pembelajaran sentra dan lingkaran dapat meningkatkan kemampuan dan potensi yang dimiliki anak usia dini dan anak autis dengan disesuaikan karakteristik yang dimiliki anak. Peran guru sangat penting dalam mengembangkan potensi-potensi anak usia dini sesuai dengan bidangnya. Dengan adanya pembelajaran sentra dan lingkungan anak normal dan anak autis dapat bekerja sama dengan baik dalam setiap kegiatan
\end{abstract}

\begin{abstract}
Abstarct
The purpose of this study was to describe the learning model of the center and the environment for normal children and autism children. This study uses a qualitative approach. Methods of data collection using observation and interviews. The results of this study obtained that the center and circle learning model can improve the abilities and potential of early childhood and autism children according to the characteristics of the child. The role of the teacher is very important in developing the potentials of early childhood in accordance with their field. With the learning center and the environment, normal children and autism children can work well together in every activity
\end{abstract}




\section{PENDAHULUAN}

Bermain adalah dunia anak dan bukan hanya sekedar memberikan kesenangan, akan tetapi juga memiliki manfaat yang sangat besar bagi anak. Melalui kegiatan bermain yang positif, anak bisa menggunakan otot tubuhnya serta dapat menstimulasi penginderaannya, menjelajahi dunia sekitarnya, dan mengenali lingkungan tempat tinggalnya termasuk di dalamnya dapat mengenali dirinya sendiri sejak dini (Tanjung, H. S., \& Nababan, S. A. 2018). Kemampuan fisik anak semakin terlatih, begitu pula dengan kemampuan kognitif dan kemampuannya untuk bersosialisasi. Dalam bahasa sederhana, bermain akan mengasah kecerdasannya sejak dini. Penerapan model ini dapat dilaksanakan secara bertahap dan dapat dimodifikasi sesuai dengan situasi dan kondisi di Indonesia. Sepanjang tetap memperhatikan prinsip-prinsip pembelajaran anak usia dini.

Model BCCT merupakan pengembangan dari model Montessori, High Scope, Reggio Emilio, dan High Star yang memfokuskan kegiatan anak di sentra-sentra, sudut-sudut, atau area-area untuk mengoptimalkan seluruh kecerdasan anak. Masing-masing sentra yang dikembangkan dalam model BCCT ini berfungsi untuk menstimulasi perkembangan anak secara kognitif dan motorik halus pada anak Wahyuningsih, D. (2020). Bermain bukan hanya sekadar memberikan kesenangan, tapi juga bermanfaat besar bagi anak. Lewat kegiatan bermain yang positif dengan menerapkan model BCCT pada anak, anak bisa menggunakan otot tubuhnya, menstimulasi penginderaannya, menjelajahi dunia sekitarnya, dan mengenali lingkungan tempat ia tinggal termasuk mengenali dirinya sendiri. Kemampuan fisik anak semakin terlatih, begitu pula dengan kemampuan kognitif dan kemampuannya untuk bersosialisasi.

Sujiono (2009:216) model pembelajaran BCCT merupakan suatu metode atau pendekatan dalam penyelenggaraan pendidikan Anak Usia Dini dan merupakan perpaduan antara teori dan pengalaman praktik. Nuryani (2012:11) menerangkan bahwa BCCT merupakan suatu konsep pembelajaran yang difokuskan pengalaman dunia nyata hadir di dalam kelas dan mendorong anak didik untuk membuat hubungan antara pengalaman, pengetahuan dan pemahaman kehidupan seharihari, sehingga anak menemukan pengalamannya secara sendiri tanpa pengaruh langsung dari guru.

Belakangan ini, banyak anak dengan kebutuhan khusus seperti, autis, hiperaktif, ADHD, cerebal palsy yang kesemuanya bisa dirangkum dalam bahasa special needs. Anak special needs atau anak dengan kebutuhan khusus termasuk anak yang mengalami hambatan dalam perkembangan perilakunya. Perilaku anak-anak ini, yang antara lain terdiri dari wicara dan okupasi, tidak berkembang seperti pada anak yang normal, padahal kedua jenis perilaku ini penting untuk komunikasi dan sosialisasi sehingga apabila hambatan ini tidak diatasi dengan cepat dan tepat, maka proses belajar anak-anak tersebut juga akan terhambat.

Penyandang autisme seakan-akan hidup di dunianya sendiri. Istilah autisme baru diperkenalkan sejak tahun 1943 oleh Leo Kanner, sekalipun kelainan itu sudah ada sejak abad-abad yang lampau. (Y. Handoyo, MPH, 2003:12). Autis adalah disabilitas perkembangan neurologis yang mempengaruhi kemampuan orang untuk berkomunikasi, memahami bahasa, dan berinteraksi dengan orang lain. Anak-anak autis akan cenderung mengasingkan diri dari situasi sosial. Secara intelektual, sebagian 
mungkin mengalami retardasi mental, tetapi sebagian lainnya mungkin cerdas dan bahkan sangat cerdas. Selain masalah dengan hubungan sosial, individu-individu autis sering seringkali memperlihatkan gerakan-gerakan tak lazim, tidak mau berubah, terlalu sensitif atau justru sangat kurang sensitif terhadap stimulasi tertentu, mangamuk, dan perilaku agresif (Irvan, M., \& Jauhari, M. N. 2019).

Dalam praktik klinis baik istilah autime, ASD (Autism Spectrum Disorders) dan PDD (Pervasive Development Disorder) sering kali digunakan secara bergantian dan saling mewakili satu dengan yang lain. (Andri Priyatna, 2010:2). Perilaku Autis digolongkan dalam 2 jenis, yaitu : (1) Perilaku yang eksesif (berlebihan) yang termasuk perilaku ini adalah hiperaktif dan tantrum (mengamuk) berupa menjerit, menyepak, menggigit, mencakar, memuku Irvan, M., \& Jauhari, M. N. (2020). Disini juga sering terjadi anak menyakiti sendiri (self abouse). (2) Perilaku defisit (berkekurangan), ditandai dengan gangguan bicara, perilaku sosial kurang sesuai, bermain tidak benar, dan emosi yang tidak tepat misalnya, tertawa tanpa sebab, menangis tanpa sebab dan melamun. (Y. Handojo, MPH, 2003: 13).

\section{METODE PENELITIAN}

Sesuai dengan metode penelitian dan permasalahan yang telah dipaparkan sebelumnya, penelitian ini merupakan penelitian kualitatif .Gunawan(2013:80) Dalam penelitian kualitatif instrument penelitian adalah peneliti sendiri. Instrumen penelitian tidak bersifat eksternal atau objektif, akan tetapi internal atau subyektif yaitu penelitiitu sendiri tanpa menggunakan tes ,angket maupun eksperimen. Oleh karena itu kehadiran peneliti secara langsung merupakan keharusan dalam penelitian kualitatif. Adapun Teknik pengumpulan data yang digunakan yaitu observasi, wawancara, dokumentasi dan triangulasi sedangkan untuk menguji keabsahan data yang telah didapat peneliti mengunakan dua Teknik untuk menguji keabsahan data tersebut yaitu dengan uji kredibilitas data dan uji konfirmability

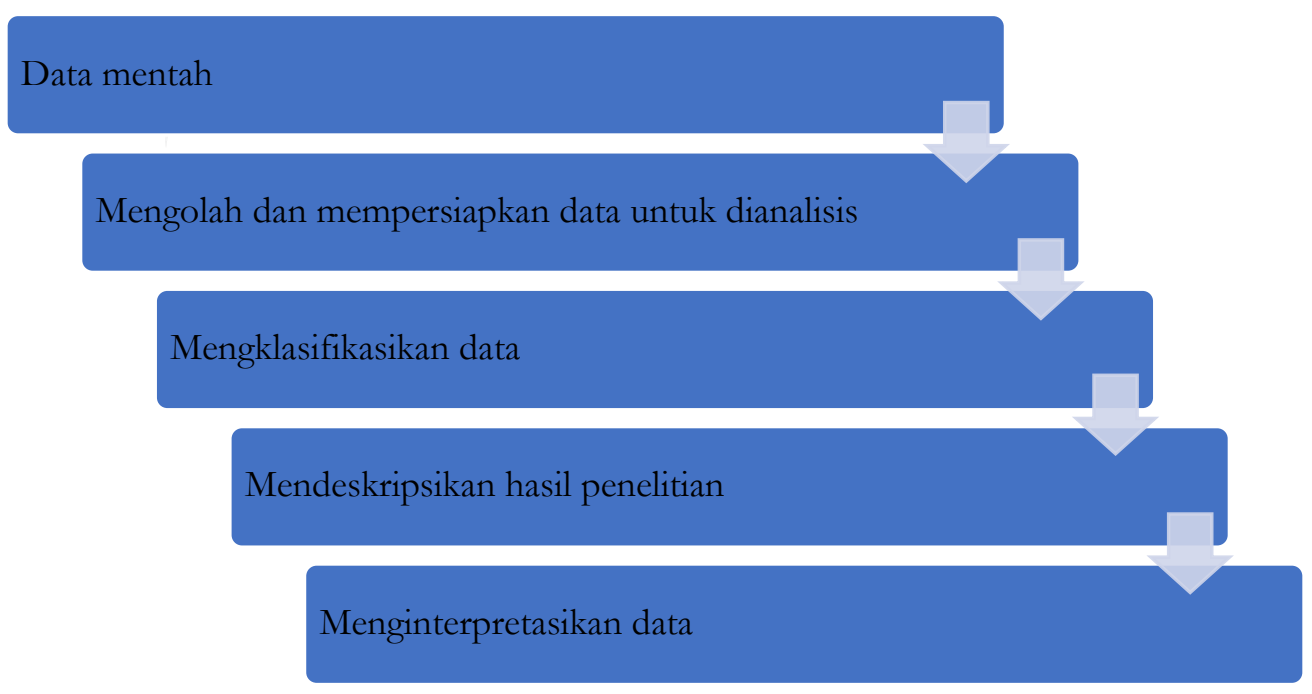

Gambar 1. Alur penelitian 


\section{HASIL DAN PEMBAHASAN}

1. Observasi partisipatif

Cara ini digunakan peneliti agar data yang diinginkan dapat diperoleh sesuai dengan yang dimaksud peneliti. Peneliti partisipatif maksudnya ialah peneliti terlibat secara langsung dan bersifat aktif dalam mengumpulkan data yang diinginkan juga peneliti kadang- kadang mengarahkan obyek yang diteliti. Obyek yang diteliti disini adalah siswa dan guru. Observasi siswa dilakukan untuk mengetahui aktifitas yang dilakukan siswa autis pada proses pembelajaran yang sedang berlangsung. Observasi guru dilakukan untuk mengetahui proses pembelajaran sudah sesuai dengan rencana pelaksanaan pembelajaran.

2. Wawancara mendalam

Hal ini dilaksanakan untuk mengetahui hal-hal yang lebih mendalam tentang pelaksanaan pembelajaran dengan model sentra dan lingkaran untuk anak normal dan beberapa anak autis karena informasi yang ingin diketahui belum dapat diketahui melalui observasi. Menurut Esterberg (2002) dalam Sugiyono (2008 : 233) mengemukakan ada tiga macam wawancara, yaitu: wawancara terstruktur, semi struktur dan tidak terstruktur. Dalam wawancara terstruktur peneliti telah menyiapkan beberapa pertanyaan untuk para informan, sedangkan dalam wawancara semi struktur dan tak berstruktur peneliti tidak menggunakan pedoman wawancara dalam menggali informasi dari informan namun peneliti tetap mencatat apa yang dikemukakan oleh informan.

Adapun langkah-langkah yang digunakan dalam penelitian ini, seperti yang diungkapkan oleh Lincoln dan Guba dalam Faisal (dalam Sugiyono, 2008 : 235) bahwa ada tujuh langkah dalam penggunaan wawancara untuk mengumpulkan data, yaitu:
a. Menetapkan kepada siapa wawancara dilakukan
b. Menyiapkan pokok-pokok masalah yang akan menjadi bahan pembicaraan
c. Mengawali atau membuka alur wawancara
d. Melangsungkan alur wawancara
e. Mengkonfirmasikan ikhtisar hasil wawancara dan mengakhirinya
f. Menuliskan hasil wawancara ke dalam catatan lapangan
g. Mengidentifikasi tindak lanjut hasil wawancara yang telah diperoleh

Wawancara yang dilaksanakan secara lisan dalam pertemuan tatap muka secara individual. Dalam penelitian ini wawancara ditujukan pada pengurus lembaga (yayasan) pendiri KB-TK AZ ZAHRAH, guru yang masih aktif, guru yang dulu pernah mengajar, wali murid yang masih aktif mengantar anaknya guna memperoleh data dalam pelaksanaan pembelajaran dengan model sentra dan lingkaran untuk anak normal dan anak autis. 
Berdasarkan hasil wawancara yang peneliti laksanakan yayasan berpendapat bahwa Model pembelajaran sentra dan lingkaran merupakan salah satu model pembelajaran yang diterapkan KBTK AZ ZAHRAH dengan harapan dapat meningkatkan kemampuan dan potensi yang dimiliki anak usia dini. Kurikulum yang digunakan KB-TK AZ ZAHRAH dalam meningkatkan kemampuan dasar anak banyak mengalami perubahan dari mulai kurikulum 2004 yaitu kurikulum berbasis kompetensi, kurikulum tingkat satuan pendidikan, dan yang sekarang pemendiknas no. 58, di samping menggunakan kurikulum tersebut, sekolah ini dalam kegiatan pembelajarannya juga menambahkan kurikulum khusus berupa materi plus. Kurikulum ini disusun dengan tetap mengacu pada permendiknas no. 58 dengan tujuan yang telah ditetapkan, sebagai salah satu bentuk keunggulan dari KB-TK Az Zahrah Surabaya.

Beyond Centers and Circles Time (BCCT) adalah metode penyelenggaraan PAUD yang berpusat pada anak yang dalam proses pembelajarannya berpusat di sentra main dan saat anak dalam lingkaran. Beyond Centers and Circles Time (BCCT) dapat dikatakan sebagai konsep belajar dimana pendidik (guru) menghadirkan dunia nyata ke dalam kelas dan mendorong anak didik membuat hubungan antara pengetahuan yang dimiliki dengan penerapannya dalam kehidupan mereka seharihari. Sentra main adalah zona atau area main anak yang dilengkapi seperangkat alat main yang berfungsi sebagai pijakan lingkungan yang diperlukan untuk mendukung perkembangan anak dalam tiga jenis permainan. Yakni main sensorimotor (fungsional), main peran, dan main pembangunan Rindaningsih, I. (2012).

Sedangkan saat lingkaran merupakan saat guru duduk bersama anak dengan posisi melingkar untuk memberikan pijakan (arahan) kepada anak yang dilakukan sebelum dan sesudah main. MetodenBeyond Centers and Circles Time (BCCT) adalah metode penyelenggaraan PAUD yang berpusat pada anak yang dalam proses pembelajarannya berpusat di sentra main dan saat anak dalam lingkaran dengan menggunakan empat pijakan. empat pijakan tersebut akan penulis jelaskan pada pembahasan berikutnya. Di Indonesia metode ini lebih dikenal dengan Sentra dan lingkaran (Seling). metode pengajaran yang menempatkan siswa pada posisi yang proposional. Pendekatan sentra dan lingkaran berfokus pada anak Yulisutiany, I. (2018).

Sentra main adalah zona atau area main anak yang di lengkapi dengan seperangkat alat main yang berfungsi sebagai pijakan lingkungan yang diperlukan untuk mendukung perkembangan anak dalam 3 jenis main. yaitu: main sensorimotor, main peran dan main pembangunan. Saat lingkaran adalah saat dimana pendidik (guru/kader/pamong) duduk bersama anak dengan posisi melingkar untuk memberikan pijakan kepada anak yang dilakukan sebelum dan sesudah main. Pembelajaran yang berpusat pada anak dan peran guru hanya sebagai fasilitator, motivator dan evaluator merupakan ciri dari metode BCCT ini, Sehingga otak anak dirangsang untuk terus berfikir secara aktif dalam menggali pengalamannya sendiri bukan sekedar mencontoh dan menghafal saja Arifin, A. R. K., \& Fardana, N. A. (2014). 
Tujuan Metode Beyond Centers And Circles Time (BCCT) Adapun tujuan dari metode Beyond Centers And Circles Time (BCCT) antara lain sebagai berikut: Dalam rangka melejitkan potensi kecerdasan anak. Howard Gardner menyatakan bahwa pada hakikatnya setiap anak ialah cerdas. Pandangan ini menentang bahwa kecerdasan hanya dilihat dari fakror IQ. Gardner melihat kecerdasan dari berbagai dimensi. Setiap kecerdasan yang dimiliki akan dapat mengantarkan anak mencapai kesuksesan Yuningsih, S., Rifai, A., \& Kisworo, B. (2018). Pendidik/guru perlu memfasilitasi setiap kecerdasan yang dimiliki anak dalam pembelajaran dan kegiatan belajar. diantaranya :

1. Kecerdasan bahasa (Linguistik) berkaitan dengan keterampilan dan persepsi mengelola kata dan bahasa.Yakni kemampuan menggunakan kata'kata secara efektif

2. Kecerdasan Logika ' matematika berkaitan dengan keterampilan dan persepsi dalam bidang angka (Numerik) dan alasan logis.

3. Kecerdasan music berkaitan dengan keterampilan dan persepsi dalam bidang music dan suara

4. Kecerdasan gerak tubuh (kinestesis) berkaitan dengan ketrampilan dan persepsi dalam bidang mengolah dan mengendalikan gerak anggota tubuh.

5. Kecerdasan gambar dan ruang (Visual'spasial) berkaitan dengan keterampilan dan persepsi dalam bidang permainan, garis, warna, bentuk, dan ruang.

6. Kecerdasan diri (intrapersonal) berkaitan dengan keterampilan dan persepsi dalam bidang kesadaran dan pengenalan terhadap diri sendiri.

7. Kecerdasan berbaur (interpersonal) berkaitan dengan keterampilan dan persepsi dalam bidang membina hubungan dengan orang lain.

8. Kecerdasan alami (naturalis) berkaitan dengan keterampilan dan persepsi dalam bidang yang berhubungan dengan alam dan lingkungan sekitar.

9. Kecerdasan rohani (spiritual) berkaitan dengan keterampilan dan persepsi dalam bidang mengolah rohani.

10. Kita harus mengingat bahwa setiap orang memiliki sembilan kecerdasan ini dan setiap hari menggunakannya dengan kombinasi yang berlainan dan setiap orang juga mempunyai delapan kecerdasan ini dengan cara mereka masing-masing.

Oleh karena itu dalam proses belajar mengajar untuk anak usia dini diharapkan dapat tercipta pembelajaran yang tidak membebani dan menyenangkan, sehingga anak aka semakin mudah menyerap apa yang mereka pelajari yakni sesuai dengan prinsip pendidikan anak usia dini yaitu belajar sambil bermain dan bermain sambil belajar. Dengan demikian akan terbentuk aspek kemampuan kognitif, afektif, dan psikomotorik anak. Dan sesuai dengan ruang lingkup kurikulum untuk anak prasekolah meliputi enam aspek perkembangan yang dicapai yaitu : 
1. Moral dan nilai'nilai agama.

2. Sosial, emosional dan kemandirian.

3. Kemampuan berbahasa.

4. Kognitif.

5. Fisik atau motorik.

6. Kreatifitas atau seni.

Anak-anak merupakan individu yang baru mengenal dunia dan belum mengetahui tata karma, sopan santun, aturan, norma, dan sebagainya. Anak perlu dibimbing agar mampu memahami berbagai hal. Usia dini merupakan saat yang sangat berharga untuk menanamkan nilai'nilai dasar dalam kehidupan yang meliputi:

1. Nilai'nilai nasionalisme.

2. Nilai'nilai agama.

3. Nilai'nilai etika.

4. Nilai'nilai moral.

5. Nilai'nilai sosial.

Bentuk-Bentuk Sentra dalam Beyond Centers And Circles Time (BCCT) dapat dijabarkan sebagai berikut :

1. Sentra Bahan Alam.

2. Sentra Main Peran Mikro atau Makro

3. Sentra Balok

4. Sentra Persiapan

5. Sentra Iman \& Taqwa (Religion Center).

6. Sentra Seni dan Kreatifitas

Model pembelajaran sentra dan lingkaran diharapkan dapat meningkatkan kemampuan dan potensi yang dimiliki anak usia dini khususnya anak autis. Kurikulum yang digunakan bagi anak-anak berkebutuhan khusus seperti autis mendapatkan pembelajaran khusus akan tetapi tetap dengan materi yang sama dengan anak normal. Berdasarkan hasil wawancara pengelola KB-TK AZ ZAHRAH merumuskan tujuan pembelajaran dengan model sentra dan lingkaran bahwa. Model sentra dan lingkaran merupakan salah satu model pembelajaran dalam pendidikan anak usia dini yang bertujuan agar dapat mengembangkan minat, bakat dan potensi anak secara optimal. Baik untuk anak normal maupun untuk anak autis. Cara mengajarkan anak normal dengan menggunakan model pembelajaran sentra dan lingkaran sangat berbeda dengan mengajarkan pada anak autis. Sangat mudah atau gampang sekali mengajar anak normal dengan menggunakan model sentra dan lingkaran yang terpenting guru sudah menyampaikan temanya, terus memberi pijakan sebelum main dan aturan aturan yang sudah dibuat bersama anak-anak. Dalam pelaksanaan model pembelajaran sentra dan 
lingkaran guru adalah fasilitator dan motivator karena setiap kegiatan yang akan dilaksanakan harus membuat anak tetap memiliki semangat dan selalu termotivasi agar dapat mengikuti kegiatan sebaik mungkin agar anak dapat mengeksplor kemampuan sebagai mana mestinya tanpa merasa terbebani Purnama, A., \& Abadi, M. I. (2019.

Dalam menggunakan model pembelajaran sentra dan lingkaran, cara mengajarkan kepada anak autispun berbeda satu sama lain. Anak autis yang ringan masih mengerti bahasa cara penanganannya tidak terlalu berat tetapi untuk autis yang berat tidak mengerti bahasa guru harus mengeluarkan tenaga yang cukup berat untuk menanganinya Sasmita, D. (2018). Untuk berbicara atau berkomunikasi dengan anak autis guru harus mengetahui perkembangan bahasanya, biasanya cara ngomongnyaperkata sambil menunjuk bendanya. Tidak semua anak autis tahu apa yang diomongkan guru, misal si R sambil ngomong kita juga harus menunjuk bendanya, si $\mathrm{S}$ mengerti yang guru omongkan dan langsung mengerjakan tapi tidak langsung ketempat yang guru perintahkan, sedangkan si U mengerti apa yang guru omongkan, tetapi si $U$ malah balik bertanya kepada guru,danngomongnya selalu di ulang-ulang.

Dalam pelaksanaan model pembelajaran sentra dan lingkaran guru adalah sebagai teman main dan menyiapkan apa yang dibutuhkan anak, untuk anak autis ada guru pendamping yang mengarahkan dan yang melatih materi yang disampaikan guru kelas. Seorang guru hendaknya harus memahami karakter setiap anak, baik anak dalam kondisi senang maupun sedih, saat anak sedih guru merangkul atau memeluk anak sambil bertanya kepada anak, apa sebabnya anak tidak mau kesekolah, setelah guru mengetahui sebabnya guru memberikan pengertian kepada anak. Strategi lain yang digunakan guru dengan cara mengajak jalan-jalan atau mengajak bermain terlebih dahulu, apabila sudah tidak rewel guru membuat kegiatan cerita pagi, dalam kegiatan ini setiap anak bercerita tentang perasaan yang dirasakan anak saat ini, setelah semua anak selesai bercerita guru memberikan pengertian pada anak yang rewel.

Perasaan seorang anak usia dini sangat cepat sekali untuk berubah, bahkan saat berangkat sekolah maupun kegiatan belajar mengajar di dalam kelas, hal inilah yang menuntut guru untuk memiliki bermacam-macam strategi agar anak dapat duduk tenang dan fokus dalam pembelajaran, macam-macam kesukaan yang dimiliki seorang anak, ada yang suka buku, jadi cara merayunya dengan buku. Jadi setiap guru harus tahu apa yang disukai anak autis, misal si S hanya mau masuk jika dipanggilkan nama teman yang dihafal S, si U tidak akan rewel jika diberi buku, karena si U senang sekali dengan buku, kalau si R merayunyadengan mengatakan kalau nanti pulang akan dijemput bapak karena si $\mathrm{R}$ rewel bila ada bapaknya.

Beberapa wali murid berpendapat bahwa dengan menggunakan model pembelajaran sentra dan lingkaran dapat meningkatkan kemampuan anak dalam bersosialisasi dan berinteraksi dengan teman lain termasuk anak autis, selain itu juga dapat meningkatkan kemandirian anak dalam mengambil sebuah keputusan saat bermain. Hal yang sama juga disampaikan oleh ibu si S, tidak semua wali murid tahu tentang model pembelajaran sentra dan lingkaran, tetapi banyak yang memperhatikan bahwa dengan model sentra dan lingkaran anak normal bisa mandiri dalam 
mengambil keputusan untuk bermain, bisa berinteraksi dengan baik sama teman-temannya, terus anak-anak itu dapat mengembangkan potensinya saat bermain sentra.

Untuk wali murid yang mempunyai anak autis banyak yang berfikir dapatkah model pembelajaran sentra dan lingkaran ini meningkatkan kemandirian anak autis dalam melakukan suatu kegiatan. Selain ibu si S ada juga wali murid yang bersyukur bisa mengetahi model pembelajaran sentra dan lingkaran, awalnya mereka tidak tahu tentang model pembelajaran anak usia dini khususnya autis, setelah diperhatikan dan dirasakan model pembelajaran sentra dan lingkaran dapat meningkatkan kemampuan anak autis, mulai dari interaksi dengan teman, kosa kata juga bertambah, bisa menerapkan beberapa hadistdi rumah. Salain dari wali murid yang aktif, wali murid yang sudah tidak aktifpun juga berpendapat yang sama, model pembelajaran sentra dan lingkaran sangat bagus bisa membuat anak autis lebih mandiri dan dapat meningkatkan kemampuan anak dalam berinteraksi, berkomunikasi walaupun hanya beberapa kata Prasetyo, T., \& Supena, A. (2021).

Banyak faktor yang dapat mempengaruhi efektifitas pembelajaran dengan model sentra dan lingkaran untuk anak normal. Untuk faktor penghambat yaitu : Kurangnya media yang digunakan saat bermain sentra, mengingat banyak densitas yang harus diberikan saat bermain sentra. Selain media keterbatasan waktu juga menjadi faktor penghambat dalam model pembelajaran sentra lingkaran. Kalau ada penghambat pastinya ada faktor pendukung untuk mempengaruhi efektifitas pembelajaran sentra dan lingkaran Priendarningtyas, A. (2017), Renata, N. (2013).

Motivasi belajar anak yang tinggi, karena anak usia dini rasa ingin tahunya sangat tinggi sehingga mendorong anak untuk belajar. Kesiapan guru dalam pembelajaran dengan menggunakan model sentra dan lingkaran, Salah satu faktor yang mendukung keberhasilan pelaksanaan proseskegiatan belajar mengajar ini didukung oleh kesiapan para gurunya sebelum guru menyampaikan materi maka para guru juga harusmempersiapkan materi yang akan disampaikan kepada anak sesuai yang ditulis dalam Rencana Kegiatan Harian yang dibuat oleh guru.

Banyak faktor yang dapat mempengaruhi efektifitas pembelajaran dengan model sentra dan lingkaran untuk anak autis. Untuk faktor penghambat yaitu : Kurangnya pemahaman guru tentang anak autis, tidak semua guru mengetahui tentang anak berkebutuhan khusus seperti autis, sehingga menyulitkan guru untuk menangani anak autis, Kurangnya guru pendamping, dalam setiap pembelajaran sentra sebaiknya anak autis didampingi dengan guru pendamping yang dapat membantu menyampaikan materi dari guru kelas Badiah, L. I., Jauhari, M. N., \& Sambira, S. (2020). Untuk faktor pendukung anak autis yaitu: Sikap orang tua yang ingin meningkatkan kemampuan anak autis, setiap orang tua pastinya menginginkan yang terbaik untuk meningkatkan kemampuan anaknya khususnya autis. Interaksi anak normal yang bisa membantu anak autis dalam meningkatkan kemampuan, karena teman sebaya anak autis bisa meningkatkan kemampuan dengan cara melihat tingkah laku dan pembiasaan anak normal. 


\section{KESIMPULAN}

Berdasarkan hasil penelitian yang telah dilakukan maka penulis dapat menyimpulkan sebagai berikut:

1. Pelaksanaan pembelajaran dengan model sentra dan lingkaran untuk anak normal dan beberapa anak autis.

Model pembelajaran sentra dan lingkaran diharapkan dapat meningkatkan kemampuan dan potensi yang dimiliki anak usia dini khususnya anak autis. Kurikulum yang digunakan KB-TK AZ ZAHRAH dalam meningkatkan kemampuan dasar anak banyak mengalami perubahan dari mulai kurikulum 2004 yaitu kurikulum berbasis kompetensi, kurikulum tingkat satuan pendidikan, dan yang sekarang Pemendiknas No 58, sekolah ini dalam kegiatan pembelajarannya juga menambahkan kurikulum khusus berupa materi plus, sebagai salah satu bentuk keunggulan dari KB-TK AZ ZAHRAH SURABAYA. Kurikulum yang digunakan bagi anak-anak berkebutuhan khusus seperti autis mendapatkan pembelajaran khusus akan tetapi tetap dengan materi yang sama dengan anak normal.

2. Tujuan pembelajaran dengan menggunakan model sentra dan lingkaran untuk anak normal dan beberapa anak autis.

Model sentra dan lingkaran merupakan salah satu model pembelajaran dalam pendidikan anak usia dini yang bertujuan dapat mengembangkan minat, bakat dan potensi anak secara optimal. Baik untuk anak normal maupun untuk anak autis.

3. Peran guru dalam pem4belajaran untuk mengoptimalkan potensi anak normal dan anak autis dalam mencapai tujuan pembelajaran.

Cara mengajarkan anak normal dengan menggunakan model pembelajaran sentra dan lingkaran sangat berbeda dengan mengajarkan pada anak autis. Sangat mudah atau gampang sekali mengajar anak normal dengan menggunakan model sentra dan lingkaran yang terpenting guru sudah menyampaikan temanya, terus memberi pijakan sebelum main dan aturan- aturan yang sudah dibuat bersama anak-anak. Dalam pelaksanaan model pembelajaran sentra dan lingkaran guru adalah sebagai teman main dan menyiapkan apa yang di butuhkan anak, untuk anak autis ada guru pendamping yang mengarahkan dan yang melatih materi yang disampaikan guru kelas.

4. Strategi dan teknik pembelajaran yang dikembangkan dalam menunjang efektifitas pembelajaran dengan model sentra dan lingkaran untuk anak normal dan beberapa anak autis.

Perasaan seorang anak usia dini sangat cepat sekali untuk berubah, bahkan saat berangkat sekolah maupun kegiatan belajar mengajar di dalam kelas, hal inilah yang menuntut guru untuk memiliki bermacam-macam strategi agar anak dapat duduk tenang dan fokus dalam pembelajaran. Strategi lain yang digunakan guru dengan cara mengajak jalan-jalan atau mengajak bermain terlebih dahulu, setiap guru harus tahu apa yang disukai anak autis. 


\section{DAFTAR PUSTAKA}

Arifin, A. R. K., \& Fardana, N. A. (2014). Peran Pendidik PAUD dalam Mengimplementasikan Pendidikan Karakter Melalui Metode Pembelajaran Sentra dan Lingkaran. Jurnal Psikologi Pendidikan Dan Perkembangan, 3(3), 188-198.

Badiah, L. I., Jauhari, M. N., \& Sambira, S. (2020). Peningkatan Keterampilan Guru Paud Dalam Menyusun Program Pembelajaran Individual Anak Berkebutuhan Khusus Di PAUD Permata Bunda. SPEED Journal: Journal of Special Education, 3(2), 95-100.

Handoyo .Y. Autisma. Jakarta Bhuana Ilmu Popular. 2003.

Irvan, M., \& Jauhari, M. N. (2019). Early Intervention For Children With Autism Spectrum Disorder Using Planning Matrix. In The 9th International Conference on Educational Technology of Adi Buana (ICETA 9).

Irvan, M., \& Jauhari, M. N. (2020, December). Family Intervention: A Systematic Learning Approach for Children with Disabilities During Pandemic Covid-19. In 1st International Conference on Information Technology and Education (ICITE 2020) (pp. 223-227). Atlantis Press.

Nuryani. Kumpulan Materi Pendidikan Anak Usia Dini.2012. Roudhotul Athfal. Istiglal. Jakarta.

Purnama, A., \& Abadi, M. I. (2019). Pengembangan Model Pembelajaran Sentra dan Lingkaran Berbasis Pendidikan Inklusi Untuk Taman Kanak-kanak (TK). Jurnal Teladan: Jurnal Ilmu Pendidikan Dan Pembelajaran, 4(1), 1-8.

Prasetyo, T., \& Supena, A. (2021). Pelaksanaan Pembelajaran Peserta Didik Berkebutuhan Khusus di Sekolah Inklusif Selama Pandemik Covid-19 Learning Implementation for Students with Special Needs in Inclusive Schools During the Covid-19 Pandemic.

Priyatna, Andri. Amazing Autism!. Jakarta. Elek Media Komputindo. 2009

Priendarningtyas, A. (2017). Pembelajaran Paud Pada Anak Autis (Penelitian Deskriptif di TK A Fitria Assyahara, Klender-Jakarta Timur). Jurnal CARE (Children Advisory Research and Education), 5(1), 49-60.

Rindaningsih, I. (2012). Pengembangan Model Manajemen Strategik Berbasis (beyond center and circle Time) BCCT Pada PAUD. PEDAGOGIA: Jurnal Pendidikan, 1(2), 213-223.

Renata, N. (2013). Peningkatan Kemampuan Bahasa Anak Autisme Melalui Permainan Balok Warna di PAUD Autis BIMA Padang (Doctoral dissertation, Universitas Negeri Padang).

Sasmita, D. (2018). Implementasi Metode Pembelajaran Sentra dan Waktu Lingkaran Pada Pembelajaran Kelompok B di PAUD Terpadu Widya Mandala Bondowoso Tahun Pelajaran $2017 / 2018$.

Sujiono, Yuliani Nurani. Konsep Dasar Pendidikan Anak Usia Dini. Jakarta. Indeks. 2009.

Tanjung, H. S., \& Nababan, S. A. (2018). Pengaruh penggunaan metode pembelajaran bermain terhadap hasil belajar matematika siswa materi pokok pecahan di kelas III SD Negeri 200407 Hutapadang. Bina Gogik: Jurnal Ilmiah Pendidikan Guru Sekolah Dasar, 3(1). 
Wahyuningsih, D. (2020). Model Pembelajaran Bcct Bagi Anak Usia Dini Sesuai Dengan Tahap Perkembangan. Dunia Anak: Jurnal Pendidikan Anak Usia Dini, 3(1), 58-69.

Yulisutiany, I. (2018). Study of Education Competency and Effect on Learning Process of BCCT Method on Educational Group of Education Age (PAUD) in Sukasari Bandung. International Journal of Educational Technology and Learning, 3(2), 69-77.

Yuningsih, S., Rifai, A., \& Kisworo, B. (2018). Penyelenggaraan pembelajaran model Beyond Centers and Circle Time (BCCT) pada anak usia dini. Jurnal Eksistensi Pendidikan Luar Sekolah (EPlus), 3(2). 